〈原 著〉

\title{
ICT ラウンドによる teicoplanin 適正使用への取り組みに関する評価
}

\author{
小林 謙一1,4) $\cdot$ 川上 朱美2,4) $\cdot$ 西堀 武明3,4)
}

\section{Effect of Intervention by the Infection Control Team on Appropriate Use of Teicoplanin}

\author{
Kenichi KobaYaShi ${ }^{1,4)}$, Akemi KaWAKAMI ${ }^{2,4)}$ and Takeaki NiShIBORI ${ }^{3,4)}$ \\ ${ }^{1)}$ Department of Pharmacy, ${ }^{2)}$ Department of Nursing, ${ }^{3)}$ Department of Infectious Disease, \\ 4) Department of Infection Control Team, Nagaoka Red Cross Hospital
}

(2010 年 9 月 27 日 受付 $\cdot 2011$ 年 3 月 1 日 受理)

\begin{abstract}
要旨
2007 年 4 月に日本化学療法学会と日本感染症学会の共同で「抗 MRSA 薬使用の手引き」がが作 成された。この手引きには, 熄酸バンコマイシン, teicoplanin(TEIC), 硫酸アルベカシンは治療 薬物モニタリング $(\mathrm{TDM})$ が必要な抗菌薬であることが示されている.しかし, 当院に損いて TEIC の TDM 実施率は著しく低いものであった。感染制御チーム(ICT) は TEIC が適正使用され ていない注意薬品であると考えた. 2007 年 4 月から ICT は, 抗 MRSA 薬の適正使用を目的に抗 MRSA 薬使用患者巡回介入 (ICT ラウンド)を開始した．ICT ラウンドでは，TEIC は治療効果を 得るために負荷投与 $(\mathrm{LD})$ 実施率向上と TDM 実施率向上を目標に取り組んだ．同時に，副作用モ ニタリングは腎機能と肝機能への影響を観察したＩCT ラウンドの効果を評価するために開始前 々開始後を比較検討した。平均治療期間は 16.4 日から 9.7 日に減少した. LD 実施率は $46.2 \%$ か ら 100.0\%になった. TDM 実施率は $30.8 \%$ から $76.5 \%$ に向上した。平均血中濃度は $8.7 \mu \mathrm{g} / \mathrm{mL}$ か ら $14.5 \mu \mathrm{g} / \mathrm{mL}$ に向上した. 2008 年度は肝機能グレード 2 以上の症例を防ぐことができた． ICT ラウンドは, TEIC の有効性と安全性を積極的に守り, 適正使用に効果的に機能しているものと考 えられた。
\end{abstract}

Key words : ICT, TDM, 抗 MRSA 薬, teicoplanin

はじめに

長岡赤十字病院 (以下, 当院) infection control team (ICT) は 2005 年 4 月に結成され, 院内感染対策活動を 開始した．2005２006 年に全職員対象標準予防策の徹 底, 2006 年 4 月 2007 年に全職員対象の感染対策関連 の講義を毎月 $1 \sim 2$ 回開催した. 院内ラウンドは 2006 年 4 月から感染管理について実施している. 抗 MRSA 薬の適正使用への試みは数多く報告2 10)されている. 当院では, 2007 年 4 月から抗 methicillin-resistant Staphylococcus aureus (MRSA) 薬適正使用を推進するた め新たに抗 MRSA 薬使用患者巡回介入(以下, ICT ラ ウンド)を導入した。

長岡赤十字病院 1) 薬剤部, 2) 看護部, 3 ) 感染症科, 4 )感染制御 チーム
従来より ICT 発足前から薬剂部への「抗 MRSA 薬使 用届出書」届出制が行われていた。 しかし，この届出制 は強制力がなく, 個別の医師へのフィードバックもして いないため, 著しく提出率が低い。そのため抗 MRSA 薬の使用患者把握が困難であり, 誰にどのような用法 · 用量で使用をしているかリアルタイムには分からなかっ た.つまり抗 MRSA 薬の使用は主治医の判断に任され ていた．この場合には，保菌患者への投与を疑われた症 例や therapeutic drug monitoring (TDM) 未実施の症例 が多くみられた。抗 MRSA 薬は血中濃度レベルに個人 差があるため，有効性と副作用を検討するために TDM が必要な抗菌薬1)である。そこで ICT ラウンドではリ アルタイムに抗 MRSA 薬使用患者を把握し, 保菌·感 染の区別2) と TDM 実施率の向上を目標に取り組んだ. 抗 MRSA 薬のなかでも teicoplanin (TEIC) はタンパク 
結合率が約 $90 \%$ と高く, 半減期が約 50 時間と長いた め, 速や加に有効血中濃度に到達させるために負荷投与 (LD) が必要な抗菌薬である.

しかし当院医師に抢いて, TEIC は他の各種抗菌薬々 比べて使用経験が少ない抗菌薬であるため, LD 未実施 の症例, vancomycin と比較して TDM 未実施の症例が 多くみられた。このように TEIC は適正使用が十分行 われて抢らず，ICTによる積極的な関与が必要な抗菌 薬であった。

ICT ラウンドを行うことでTEIC の使用量減少4,5,7), 使用期間減少5,7), LD 実施率向上 6,7$)$, TDM 実施率向 上6)につながった報告がある.しかし, 副作用(肝機能 障害と腎機能障害)についてはレトロスペクティブに解 析した報告 ${ }^{11 \sim 14)}$ はあるが，ICT ラウンドが副作用を防 御した報告は見当たらなかった。

今回我々は, ICT ラウンド実施前 1 年間と実施後 1 年目抢よび 2 年目の TEIC の使用期間, 使用量, LD 実 施率, TDM 実施率と副作用について比較することで, ICT ラウンドによる TEIC 適正使用への取り組みに関 する評価をしたので報告する。

\section{方法}

\section{1. 調查期間}

2006 年 4 月 2007 年 3 月 (2006 年度) ICT ラウンド 開始前, 2007 年 4 月 2008 年 3 月 (2007 年度) ICT ラ ウンド開始 1 年目, 2008 年 4 月 2009 年 3 月 (2008 年 度) ICT ラウンド開始 2 年目までの 3 年間とした。

\section{2. 調查対象}

細菌検查検体 MRSA 陽性 (図 1)で TEIC を 3 日以上 投与した患者 44 名 (男性 25 名, 女性 19 名, 男性平均 年齢 $70.5 \pm 21.1$ ，女性平均年齢 $59.8 \pm 22.7)$ を対象とし た.

\section{3. 調查項目}

平均治療期間 (日), 平均使用力価 (mg/日), $\mathrm{LD}$ 実施 率 $(\%), \operatorname{TDM}$ 実施率 $(\%)$, 目標血中濃度達成率 $(\%)$, 平均血中 TEIC 濃度 $(\mu \mathrm{g} / \mathrm{mL})$, 血中 TEIC 濃度 $(\mu \mathrm{g} /$ $\mathrm{mL}$ ), 治療開始前と終了時の肝機能検査值としてアス パラギン酸アミノ基転移酵素(AST) とアラニンアミノ 基転移酵素 (ALT) 抢よび腎機能検査值として血清クレ アチニン (Scr)とした.

\section{TEIC の目標血中濃度}

$\mathrm{TEIC}$ 投与 3 日終了以降のトラフ $10 \sim 20 \mu \mathrm{g} / \mathrm{mL}$ とし た ${ }^{11,15)}$.

\section{5. 肝機能の評価}

肝機能異常は投与前の肝機能 (AST, ALT) が終了時 50\%を越えて ${ }^{12}$ ) そのうち正常值(施設基準 : AST8〜 40 $\mathrm{IU} / \mathrm{L}, \mathrm{ALT} 5 \sim 45 \mathrm{IU} / \mathrm{L}$ ) を外れた症例とした. 重症の肝 機能異常は投与開始前の肝機能(AST, ALT) が「医薬品

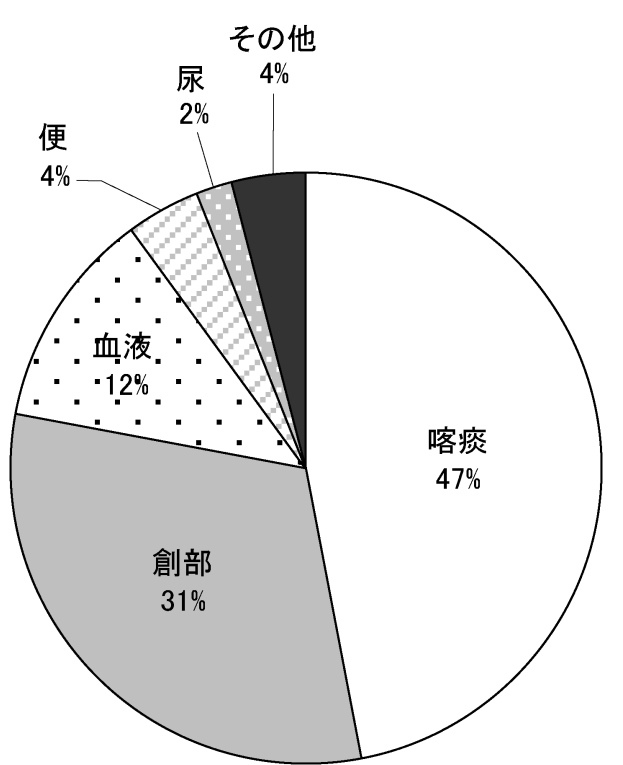

図 1 対象患者 MRSA 検出部位 $(n=51)$ 同一症例重複検体あり

等の副作用の重篤度分類基準について」(厚生省薬務局 安全課長通知, 医薬品等の副作用の重症度分類基準につ いて, 薬安第 80 号) 肝機能グレード $2(100 \sim 500 \mathrm{IU} / \mathrm{L}$ 以上) 以上に上昇した症例 ${ }^{12)}$ とした.

\section{6. 腎機能の評価}

Scr が治療開始前の值の $50 \%$ を越える上昇，または $0.5 \mathrm{mg} / \mathrm{dL}$ を越える上昇を示したものを腎障害発現と判 定した ${ }^{111}$.

\section{ICT ラウンド}

薬剂部が「抗 MRSA 薬使用患者一覧」を作成し，そ れを基に ICT が抗 MRSA 薬使用患者 ICT ラウンド シート（以下，ラウンドシート）(表 1)を作成した. ラウ ンドシートには抗 MRSA 薬の種類と用法・用量, 白血 球数 (WBC), C 反応性蛋白 (CRP), Scr, BUN, AST, $\mathrm{ALT}$, 血中 TEIC 濃度, 細菌検查結果, ICT ラウンド 時のコメント内容などを随時記載した，ICT ラウンド は感染制御医師 (ICD), 感染管理看護師 (ICN), 感染制 御薬剂師 (BCICPS) が月曜日と木曜日の週 2 回定期的に 行った。観察中には定期日以外にも必要に応じて実施し た.

\section{8. 集計}

調査対象患者のラウンドシートを基に集計した。

\section{結果}

平均治療期間は 2006 年度 16.4 日，2007 年度 10.5 日， 2008 年度 9.7 日と減少し, 1 日当たりの平均使用力価 は 2006 年度 260 力価, 2007 年度 280 力価, 2008 年度 360 力価と増加した。

$\mathrm{LD}$ 実施率は 2006 年度 $46.2 \%, 2007$ 年度 $78.6 \%$ ， 
環境感染誌 Vol. 26 no. 3, 2011

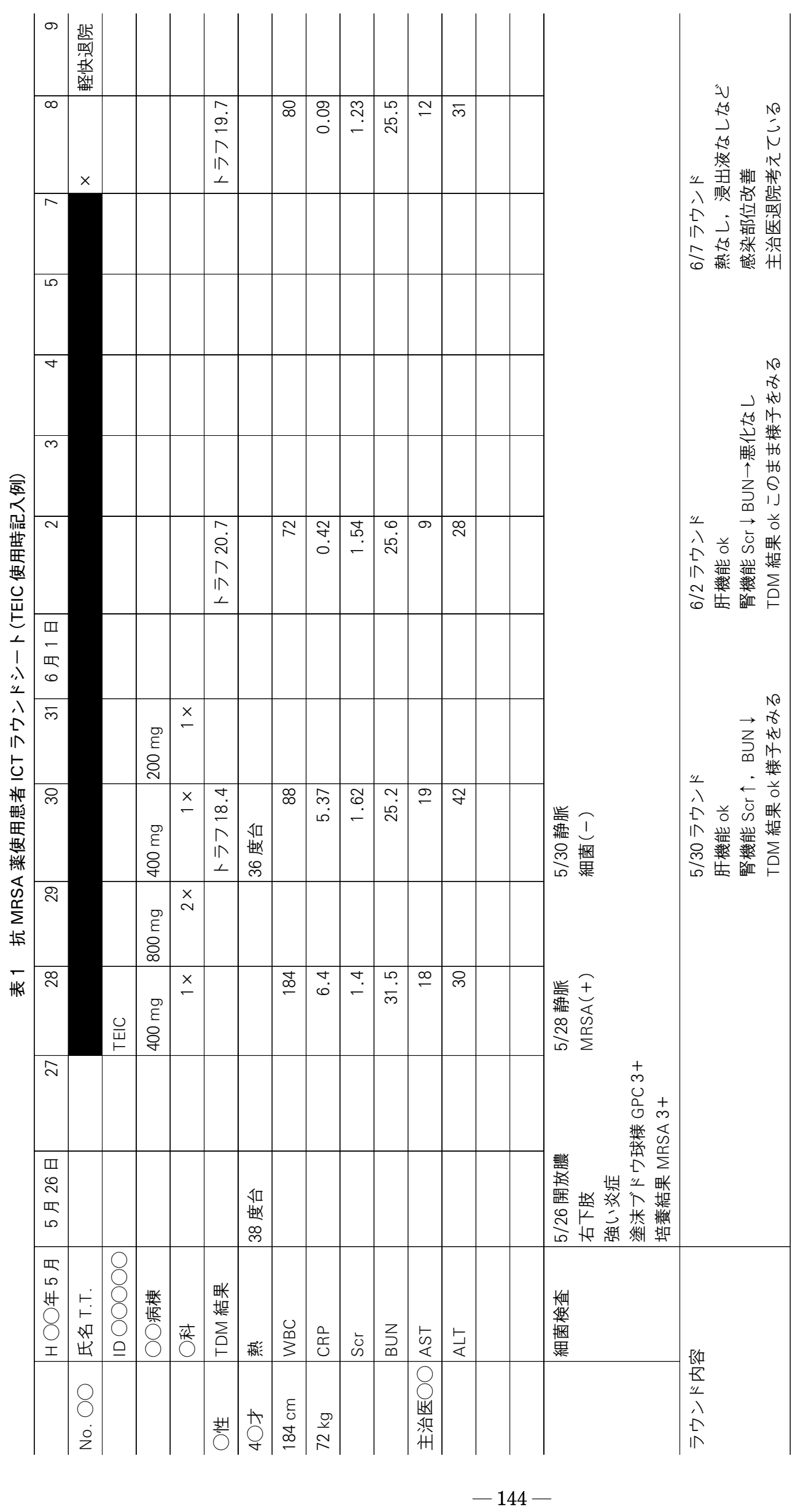


表 2 TEIC 使用症例の治療前後の AST と ALT $(n=43)$ と $\operatorname{Scr}(n=38)$ および血中濃度 $(n=26)$

\begin{tabular}{|c|c|c|c|c|c|c|c|c|c|}
\hline \multirow{2}{*}{ 年 度 } & \multirow{2}{*}{ 症 例 } & \multicolumn{2}{|c|}{$\operatorname{AST}(I U / L)$} & \multicolumn{2}{|c|}{$\operatorname{ALT}(I \cup / L)$} & \multicolumn{2}{|c|}{$\operatorname{Scr}(\mathrm{mg} / \mathrm{dL})$} & \multicolumn{2}{|c|}{ 血中濃度 $(\mu \mathrm{g} / \mathrm{mL})$} \\
\hline & & 治療前 & 治療後 & 治療前 & 治療後 & 治療前 & 治療後 & 初回測定 & 2 回目測定 \\
\hline \multirow{13}{*}{2006 年度 } & No. 1 & 21 & 85 & 20 & 72 & - & 1.26 & - & - \\
\hline & No. 2 & 26 & 22 & 7 & 7 & 1.54 & 1.74 & - & - \\
\hline & No. 3 & 15 & 17 & 4 & 5 & 1.10 & - & - & - \\
\hline & No. 4 & 11 & 7 & 28 & 9 & 0.49 & 0.48 & 18.3 & - \\
\hline & No. 5 & 38 & 124 & 23 & 125 & 0.52 & 0.55 & - & - \\
\hline & No. 6 & 77 & 114 & 140 & 117 & 0.53 & 0.41 & - & - \\
\hline & No. 7 & 20 & 15 & 17 & 6 & 0.28 & 0.25 & - & - \\
\hline & No. 8 & 20 & 132 & 8 & 62 & 1.08 & 1.17 & 4.3 & - \\
\hline & No. 9 & 27 & 31 & 10 & 8 & $\because 207$ & $\because 48 \%$ & 6.1 & - \\
\hline & No. 10 & 17 & 41 & 26 & 38 & 0.69 & 0.64 & - & - \\
\hline & No. 11 & 22 & 21 & 22 & 18 & - & - & 6.1 & - \\
\hline & No. 12 & 11 & 40 & 138 & 120 & 1.16 & 1.15 & - & - \\
\hline & No. 13 & 154 & 70 & 106 & 102 & 0.52 & 0.57 & - & - \\
\hline \multirow{14}{*}{2007 年度 } & No. 14 & 56 & 30 & 71 & 42 & 0.51 & 0.46 & - & - \\
\hline & No. 15 & 22 & 18 & 14 & 19 & 2.03 & 1.65 & - & - \\
\hline & No. 16 & 15 & 20 & 10 & 11 & 0.52 & 0.53 & - & - \\
\hline & No. 17 & 18 & 22 & 4 & 11 & 2.83 & 2.77 & 12.2 & - \\
\hline & No. 18 & 42 & 30 & 65 & 19 & 0.95 & 1.05 & - & - \\
\hline & No. 19 & 9 & 14 & 6 & 11 & 0.59 & 0.53 & 6.6 & - \\
\hline & No. 20 & 47 & 264 & 24 & 94 & 1.24 & 1.03 & 14.8 & - \\
\hline & No. 21 & 23 & 28 & 15 & 30 & 0.40 & 0.41 & - & - \\
\hline & No. 22 & 32 & 64 & 24 & 35 & - & - & 7.4 & 10.5 \\
\hline & No. 23 & 20 & 52 & 12 & 30 & 0.34 & 0.30 & 8.4 & - \\
\hline & No. 24 & 25 & 31 & 28 & 34 & 0.85 & 0.62 & 25.0 & - \\
\hline & No. 25 & 26 & 36 & 18 & 29 & 0.87 & 1.09 & 20.8 & - \\
\hline & No. 26 & 32 & 74 & 49 & 129 & 0.48 & 0.47 & 4.9 & - \\
\hline & No. 27 & 43 & 164 & 23 & 114 & 0.77 & 0.76 & 4.7 & - \\
\hline \multirow{17}{*}{2008 年度 } & No. 28 & 28 & 33 & 30 & 41 & 0.58 & 0.45 & 11.3 & - \\
\hline & No. 29 & 18 & 26 & 16 & 43 & 1.07 & 0.93 & 3.9 & 12.4 \\
\hline & No. 30 & 17 & 35 & 19 & 85 & 0.70 & 0.70 & 12.3 & - \\
\hline & No. 31 & 21 & 19 & 15 & 15 & 0.31 & 0.24 & 20.9 & - \\
\hline & No. 32 & 23 & 50 & 23 & 41 & 0.47 & 0.53 & 5.0 & - \\
\hline & No. 33 & 30 & 39 & 38 & 68 & 0.51 & 0.56 & - & - \\
\hline & No. 34 & - & - & - & - & - & - & - & - \\
\hline & No. 35 & 27 & 21 & 31 & 17 & 0.73 & 0.71 & 17.4 & - \\
\hline & No. 36 & 13 & 13 & 9 & 17 & 0.61 & 0.59 & 9.6 & - \\
\hline & No. 37 & 15 & 22 & 24 & 55 & 0.89 & 0.78 & 13.6 & - \\
\hline & No. 38 & 23 & 32 & 44 & 72 & 0.71 & 0.64 & - & - \\
\hline & No. 39 & 21 & 52 & 10 & 60 & - & - & 8.7 & - \\
\hline & No. 40 & 19 & 28 & 10 & 11 & 0.88 & 0.75 & 12.6 & - \\
\hline & No. 41 & 24 & 22 & 9 & 8 & 1.19 & 0.96 & 16.8 & - \\
\hline & No. 42 & 37 & 35 & 11 & 29 & 0.61 & 0.58 & 9.8 & 23.4 \\
\hline & No. 43 & 39 & 29 & 21 & 23 & 0.43 & 0.43 & 24.7 & - \\
\hline & No. 44 & 27 & 25 & 29 & 29 & 0.37 & 0.28 & - & - \\
\hline
\end{tabular}

太字数字は TEIC 投与で肝機能異常になった症例

枠は TEIC 投与でグレード 2 以上の肝機能障害となった症例

$\therefore$ 枠は TEIC 治療後に S C r が TEIC 治療前の值の $50 \%$ を超える上昇をした症例

枠は目標血中 TEIC 濃度を達成した症例 
2008 年度 $100.0 \%$ と向上した。 TDM 実施率は 2006 年 度 $30.8 \%, 2007$ 年度 $64.3 \%, 2008$ 年度 $76.5 \%$ と向上 した。目標血中濃度達成率は 2006 年度 $25.0 \%, 2007$ 年度 $55.6 \%, 2008$ 年度 $76.9 \%$ と向上した. 平均血中濃 度は 2006 年度 $8.7 \mu \mathrm{g} / \mathrm{mL}, 2007$ 年度 $12.0 \mu \mathrm{g} / \mathrm{mL}$, 2008 年度 $14.5 \mu \mathrm{g} / \mathrm{mL}$ と向上した.

TEIC の治療後, 2006 年度の肝機能異常は 5 症例, このうちグレード 2 以上の肝機能障害症例は 3 症例で あった. 2007 年度の肝機能異常は 5 症例, このうちグ レード 2 以上の肝機能障害症例は 3 症例であった。 2008 年度の肝機能異常は 5 症例, このうちグレード 2 以上の肝機能障害症例はなかった. TEIC 治療開始前, 正常な Scr 症例では治療後に腎機能障害発現はなかっ た。治療開始前から腎機能障害であった 1 症例は, TEIC 治療開始後急速に腎機能障害が悪化した。血中 TEIC 濃度は $30 \mu \mathrm{g} / \mathrm{mL}$ を越える症例はなかった(表 2)。

\section{考察}

抗菌薬の適正使用で重要なことは「有効性を高めるこ と」,「副作用を防止すること」，「耐性菌の発現を抑制す ること」，「経済的であること」である．TEICの適正使 用に拈いても例外ではない。これらを実践するためには LD 実施, TDM 実施は欠かせないものである. 今回我 々は，LD 実施率と TDM 実施率を向上させて速やかな 有効血中濃度への到達と患者個々の用量設定が実践でき たことで，使用期間を減少させることが出来たものと考 えた. TEIC 維持量 200 力価の投与では目標血中濃度 (10〜20 $\mu \mathrm{g} / \mathrm{mL})$ に到達することが困難な症例を経験し， ICT ラウンドで TEIC 維持量 400 力価の投与を提案し たことで，1 日当たりの平均使用力価が増加したものと 考えた．MRSA は TEIC に対する感受性が低下してき ている報告16)がある。そのため TEIC 維持量を増加し て血中 TEIC 濃度を上げることが必要である。しか し, 血中 TEIC 濃度を上げる場合には副作用の管理が 重要になってくる.

TEICの肝機能異常について, 船越ら ${ }^{12)}$ はレトロスペ クティブな研究で血中 TEIC 濃度と肝機能異常発現率 に正の相関があり, 特にトラフ $20 \mu \mathrm{g} / \mathrm{mL}$ 以上の症例で は 40\% $(\mathrm{n}=10)$ が肝機能異常となり，そのうち 2 症例は グレード 2 以上の肝機能障害が発生したことを報告し ている.

そこで我々は, TEIC で治療中の患者の肝機能を連日 確認し, 肝機能異常が発生した患者の主治医に対して注 意喚起を促し, 状況によっては薬剂変更や投与中止を考 慮してもらうことを説明した。これにより 2008 年度に はグレード 2 以上の肝機能障害の発生を防ぐことがで きたものと考えられる.

炭ら ${ }^{11)}$ は副作用と血中濃度の関係で, $30 \mu \mathrm{g} / \mathrm{mL}$ を越
したところで腎障害発現率が高くなったことを報告して いる. 戸田ら ${ }^{14)}$ は $20 \mu \mathrm{g} / \mathrm{mL}$ を超えた症例に対して腎機 能検査值を指標に安全性を検討し, 安全性は有意な変動 はなかったことを報告している.

今回，正常腎機能患者では，添付文書に記載されてい る「通常, 成人には TEIC として初日 $400 \mathrm{mg}$ (力価) 又 は $800 \mathrm{mg}$ (力価)を 2 回に分け, 以後 1 日 1 回 $200 \mathrm{mg}$ (力価) 又は $400 \mathrm{mg}$ (力価)を 30 分以上かけて点滴静注 する」の方法で治療し定常状態の血中 TEIC 濃度が 30 $\mu \mathrm{g} / \mathrm{mL}$ を超える症例がなかったことから, TEICによ る腎機能障害が生じなかったものと考えられる。

我々が ICT ラウンドを実施するにあたり，抗 MRSA 薬の使用患者を把握するため薬剤部が新たに「抗 MRSA 薬使用患者リスト」を作成した。この「抗 MRSA 薬使用患者リスト」を作成することで, 薬剤師 は TEICの初回投与患者を把握することができ，LDの 処方がない症例に対して疑似照会し主治医にLDを行え る分の処方を追加してもらった. 2008 年度, LD 実施 率が 100.0\%を達成できたのは薬剤師が疑似照会をもれ なく行ったと考えられるＩCT ラウンドでTDM未実 施の症例には主治医に TDM 実施を依頼した。この際, ICT は主治医に対して TDM の必要性と採血のタイミ ングを説明した。これによりTDMの必要性を理解した 医師が他の症例で TEICを使用する場合，処方と同時 にTDM をオーダーする症例が増え，TDM 実施率が向 上したものと考えられる.

これらのことから，ICT ラウンドを継続的に行うこ とが TEICの有効で安全な使用に貢献したことを強く 示唆した.

本論文は第 25 回日本環境感染学会総会 $(2010$ 年東京)にて発 表した内容に加筆したものである.

利益相反について : 利益相反はない.

\section{文献}

1) 社日本感染症学会, 袖日本化学療法学会: 抗 MRSA 薬使用の手引き, 2007 .

2）村川幸市，三笠桂一，小泉 章，徳谷純子，佐野麗 子, 増谷喬之, 他 : 奈良県立医科大学附属病院に打け る感染対策チーム (ICT)の MRSA 対策について. 環境 感染誌 2004; 19(2): 281-6.

3）久保裕子, 酒井義朗, 有馬千代子, 鸖田美恵子, 三宅 美穂, 升永憲治, 他 : 抗菌薬の適正使用に関する当院 ICT の取り組み一指定抗菌薬使用届出制度導入後にお ける MRSA 陽性患者数の推移も含めて一. 環境感染 誌 2008; 23(3): 201-5.

4）丸山久美子, 藤井裕史, 高橋利弘, 伊藤清隆 : ICT の 病棟巡視の効果について一MRSA 検出患者を中心に 一. 環境感染誌 $2007 ; 22(3):$ 193-6.

5）田中広紀, 並木美加子, 宇賀神和久, 丸茂健治, 川野 
留美子, 田口和三，他 : 昭和大学藤が丘病院における 抗 MRSA 薬の適正使用へ向けた ICT の取り組み. 医 療薬 2007; 33(7): 607-12.

6) 山下和彦, 中村任, 田中健太, 李宗子, 木下承 皓, 横山直樹, 他：ICT 院内ラウンドによる抗 MRSA 薬適正使用への取り組みに関する評価. 環境感染誌 2008; 23 (5): 366-70.

7）西圭史, 中村貴枝子, 岡崎充宏, 永井茂, 小林 治, 河合 伸：抗 MRSA 注射薬の適正使用を目的々 した ICT ラウンドの効果. 環境感染誌 2007; 22 (2): 85-90.

8）小阪直史, 国府孝敏, 杉岡信幸, 山田幸司, 京谷憲 子, 廣瀬有里, 他 : 抗菌薬適正使用推進チームによる 抗 MRSA 薬使用適正化の試み. 環境感染誌 2005; 20(4): 237-42.

9）本田勝亮, 稲垣啓太, 大貫上し子, 釋 悦子, 中村み ぞり，志賀大介：抗 MRSA 薬の適正使用を目的とし た ICT 介入の効果. 医療薬 2008; 34(12): 1120-6.

10）西岡達也, 岡本和恵, 甲斐幸代, 井澤初美, 但馬重 俊, 服部英喜 : ICT 活動による抗 MRSA 薬適正使用 化の試み．環境感染誌 2009; 24(2): 119-22.

11）炭 昌樹, 小西廣己, 星野伸夫, 磯野哲一郎, 套内徳 蔵, 山路 昭: グリコペプチド系抗菌薬による副作用
と血中濃度の関係. TDM 研究 2010; 27 (1): 10-5.

12）船越幸代, 山崎美保, 大和浩之, 中村 護, 久賀谷幸 昌, 大野静子，他：ティコプラニンの初期投与設計に お薬剂師介入の効果一血漿中濃度と臨床効果の比 較一. 医療薬 2007; 33(7): 571-7.

13）樋口則英, 内田華奈子，桝原克紀，塚元和弘，北原隆 志, 一川暢宏, 他 : テイコプラニン投与中の肝機能検 查值異常変動の調查解析. 日病薬師会誌 2006; 42(10): 1321-4.

14） 戸田康裕, 山田 享 : MRSA 感染症治療に打けるテイ コプラニンの血中トラフ濃度と有効性及び安全性. TDM 研究 2009; 26(4): 111-7.

15）森田邦彦：PK/PD からみた抗菌薬適正使用の実際(特 集 PK/PD による抗菌薬の適正使用). 薬事 2004; 46: 2157-63.

16) 塩谷譲司, 竹花和美 : 当院分離 MRSA の各種抗菌薬 に対する感受性の 5 年間の年次推移. Jpn J Antibiotics 2004; 57(2): 62-9.

〔連絡先：干940-2085 長岡市千秋 2 丁目 297 番地 1 長岡赤十字病院薬剂部 小林謙一 E-mail:mr-b@nagaoka.jrc.or.jp] 
Effect of Intervention by the Infection Control Team on Appropriate Use of Teicoplanin

\author{
Kenichi KobaYaSHI ${ }^{1,4)}$, Akemi KaWAKAMI ${ }^{2,4)}$ and Takeaki NiShIBoRI ${ }^{3,4)}$ \\ 1) Department of Pharmacy, 2) Department of Nursing, ${ }^{3)}$ Department of Infectious Disease, \\ ${ }^{4}$ Department of Infection Control Team, Nagaoka Red Cross Hospital
}

\begin{abstract}
"Anti-MRSA medicine use guidance" was established jointly by the Japan Society of Chemotherapy and Japanese Association for Infectious Diseases in April 2007. Therapeutic drug monitoring (TDM) is necessary for this guidance when using vancomycin hydrochloride, teicoplanin (TEIC), and sulfuric acid arbekacin. However, the TDM execution rate of TEIC was remarkably low in the Nagaoka Red Cross Hospital. The infection control team (ICT) thought that TEIC required extra attention. ICT began rounds of patients receiving anti-MRSA agent (ICT rounds) to establish correct use of anti-MRSA agents in April 2007. In the ICT round, the TEIC aimed at loading dose (LD) execution rate improvement and TDM execution rate improvement to obtain therapeutic gain. The side effects were monitored based on the influence on kidney function and liver function at the same time. Comparisons were made before and after beginning the study to evaluate the effect of ICT rounds. The average treatment period decreased from 16.4 days to 9.7 days. The LD execution rate increased from $46.2 \%$ to $100.0 \%$. The TDM execution rate improved from $30.8 \%$ to $76.5 \%$. The average blood level increased from $8.7 \mu \mathrm{g} / \mathrm{mL}$ to $14.5 \mu \mathrm{g} / \mathrm{mL}$. Occurrence of liver function more than grade 2 was prevented in fiscal year 2008. The ICT rounds were considered to positively affect the effectiveness and the safety, and encouraged correct use of TEIC.
\end{abstract}

Key words : ICT, TDM, anti-MRSA medicine, teicoplanin 